\title{
Experimental Analysis of Thermal Efficiency of Mud Improved Cookstove With Variation of Different Parameters and Economic \\ Analysis
}

\author{
Hari Bahadur Darlami ${ }^{1, *}$, Bhakta Bahadur Ale ${ }^{1}$, Govind Raj Pokharel ${ }^{2}$ \\ ${ }^{I}$ Tribhuvan University, Institute of Engineering, Pulchwok Campus, Lalitpur, Nepal \\ ${ }^{2}$ Tribhuvan University, Institute of Engineering, Thapathali Campus, Kathmandu, Nepal \\ Corresponding Email: haridarlamieioe.edu.np
}

\begin{abstract}
:
Most of the rural people of Nepal use fuelwood for cooking and space heating in residential sector. Government of Nepal has announced to make Nepal as a smokeless country by replacing traditional cookstoves. Two pot mud improved cookstove is one of the most promoted cookstoves in the context of Nepal. There is a need to study the effects of different parameters on mud improved cookstove for its better performance. The objective of this work is to study the effect of variation of different parameters on two pot mud ICS and identify parameters for its better performance. Power test of cookstove, specially focusing on thermal efficiency, has been performed by changing different parameters. Effect of varying fuel feeding rate, chimney height, opening area of air fuel inlet, inlet area of interconnecting tunnel, combustion chamber height, grate height and insulating material on thermal efficiency have been studied individually. Then cookstove has been developed by different best combinations such as a) geometrical parameters b) use of grate and insulations in best geometrical parameters and formation of channel on the opening. Thermal efficiency of modified cookstove increased from $18 \%$ to $25.6 \%$; i.e. the increment of $7.60 \%$. Economic analysis of different thermal efficiencies cookstove has been performed.
\end{abstract}

Keywords: Firepower, Efficiency, Grate, Combustion Chamber Height, Chimney, Insulation, Net Benefit

\section{Introduction}

Biomass is one of the widely available renewable energy resources which is using for cooking and space heating for long time. In the context of Nepal, $60.9 \%$ people are using fuelwood cooking purpose [1]. Use of improved cookstove by improving thermal efficiency and combustion performance can reduce adverse effects on human health, reduce energy consumption and contribute to environmental aspects [2]. About 16 million hector of forests is being consumed as cooking fuel annually throughout the world. Fuelwood consumption and subsequent environmental pollution can be reduced by improving the thermal efficiency of cookstove and through optimum use of biomass fuel [3]. Till date around 1.3 million improved cookstove (ICS) has been disseminated and still about 2 million people are using traditional cookstove. According to Biomass Strategy 2017, it has been planned to make "Indoor Air Pollution free Nepal" by 2022 through the promotion of clean cooking technologies in all households and promote modern clean energy in all the households using solid biomass by 2030 [4].
Research work should be done to develop high performance cookstove in terms of thermal efficiency and emission parameters. From the literature review, the following parameters have been identified as vital for cookstove performance:

Thermal efficiency is highly influenced by fuel feeding rate and has maximum value at a certain range $[5,6,7]$.

Chimney should be made with optimum combination of height and diameter of chimney [8]. Chimney controls the mass flow rate of incoming air [9]. Variation of chimney height affects the performance of cookstove [10].

If the height of the combustion chamber is less than the flame height, the flame will touch the cold pot which will result in quenching of flame, incomplete combustion of fuel, deposition of soot at the bottom of the pot and increase in the emission of pollutants [11]. On the other hand, if combustion chamber's height is too high, there is possibility of less heat transfer to the pot due to quenching of the flame.

A side opening in the stove has the purpose of air and fuel inlet. Fuel burning rate, temperature of combustion chamber and air supply is controlled by side opening. 
There is also loss of heat through radiation and convection by opening. Thus, a side opening has a profound influence on the efficiency of the cookstove [12].

Shape and size of the interconnecting tunnel affects the draft of air flow, turbulence of flue gases and combustion process of the cookstove. Diverging and converging tunnels have more resistance to flow of flue gases and flame. It also creates more turbulence on the flue gases. On the other hand, tunnels with small diameter creates more pressure drop [8]. Purpose of modification of pathway to second pot is to increase the efficiency of heat transfer to second pot, swirling of incoming air and flue gases. Swirling in incoming air increases the turbulence of air in combustion chamber resulting in increase of thermal efficiency [7].

Use of insulation layer in the combustion chamber reduces the heat transfer to walls of cookstove. This results in high combustion chamber temperature which increases combustion efficiency and ultimately thermal efficiency [13].

Use of the grate increases the thermal efficiency of cookstove. The primary air coming from below the grate is heated from the char and ash. Grate also aids in proper burning of char [7]. Thermal efficiency of cookstove can be improved by $3 \%$ to $5 \%$ by using grate [14].

Seconary air ensure proper and complete combustion of fuel. It increases thermal efficiency and improves quality of emission parameters [15].

Fuel burning rate, temperature of combustion chamber and air supply is controlled by side opening. There is also loss of heat through radiation and convection by opening.

\section{Materials and Methods}

\subsection{Fabrication of cookstove}

Two pot raised mud ICS of size $82 \times 40 \times 28 \mathrm{~cm}$ has been fabricated by using solid bricks, supporting structure parts and additives which is promoted by Alternative Energy Promotion Center (AEPC) Mud used for the fabrication of brick was composed up of $5 / 8$ fraction clay or local mud, 2/8 fraction rice husk or saw dust and 1/8 fraction cow or buffalo dung parts by volume. Rectangular shaped bricks have been fabricated for wall of cookstove and square shape bricks for chimney by using moulds.

\subsection{Experimental analysis}

For the analysis of cookstove parameters, experiment has been performed at Stove Lab of Pulchowk Campus,
Institute of Engineering, Tribhuvan University, Lalitpur, Nepal. Power test was done for the evaluation of thermal efficiency.

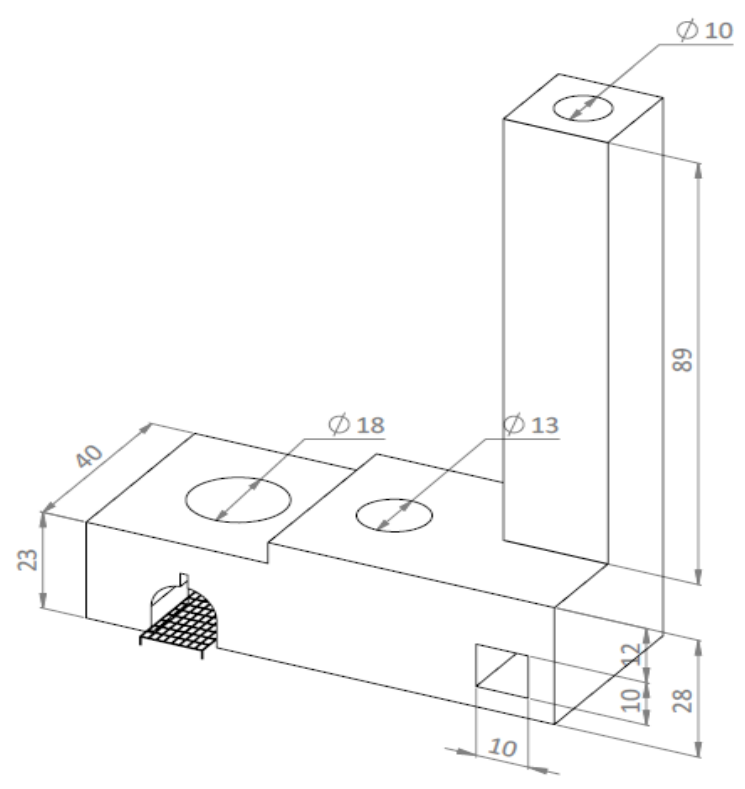

Figure 1: Schematic drawing cookstove

Thermal efficiency of cookstove has been calculated by using "Power Test". Maintaining constant power during Water Boiling Test (WBT) is difficult and power variation results in data with high standard deviation and variance. The stove power varies according to the person supplying fuelwood to cookstove and for the same person, it depends on the steadiness of fuelwood feeding. To remedy this problem, power test was devised. While most of the procedures are similar to cold start of WBT, some aspects are considered differently. First of all, the test has been conducted for one hour and secondly, constant fuel feeding rate has been maintained. The amount of wood to be supplied is divided in different batches of equal weight and is fed to stove at constant time intervals. All other protocols for testing were of Water Boiling Test 4.2.3. version [16]. For the calculation of thermal efficiency of cookstove, excel sheet provided by Global Alliance for Clean Cookstove has been used.

\subsection{Economic analysis}

Economic analysis of the cookstove has been done for the sustainability of the project. Cost benefit analysis and marginal adaptation cost has been calculated for single cookstove.

\section{Results and Discussions}




\subsection{Thermal efficiency at different firepower}

Input fuel feeding rate has been varied considering fire power range from $3.3 \mathrm{~kW}$ to $6.6 \mathrm{~kW}$ to find the optimum feeding rate as shown in Figure 2.

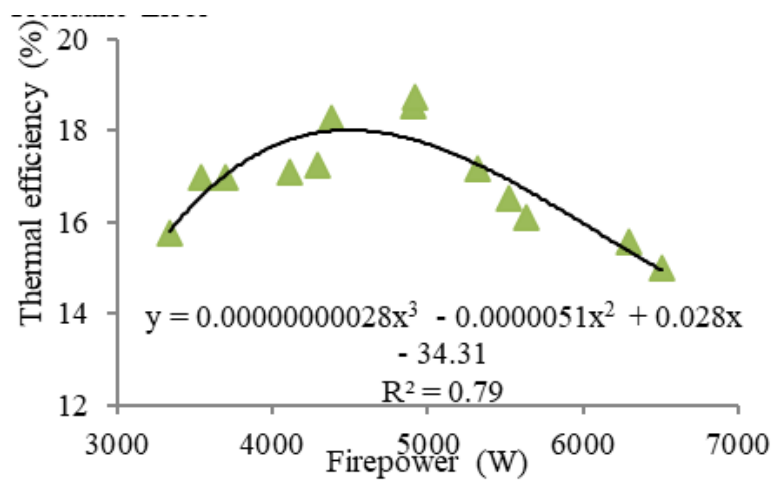

Figure 2: Thermal efficiency of cookstove at different firepower

As the fuel feeding rate increases, the efficiency first increases, reaches maximum value, and then decreases. The reason for low efficiency at lower fuel feeding rate is due to quenching of flame because of high excess air ratio. For higher fuel feeding rate, there is lack of air for complete combustion because of which the efficiency decreases. The shape of the graph is inverted bowl shape which is in accordance with the literature [7,17]. From polynomial equation of the graph, its maximum value has been found at value $4.5 \mathrm{~kW}$ and corresponding thermal efficiency $18 \%$. Feeding rate for further experiments has been maintained as per optimum firepower.

\subsection{Thermal efficiency at different chimney height}

Chimney height of the cookstove has been varied from $81 \mathrm{~cm}$ to $132 \mathrm{~cm}$ with fixed chimney hole diameter of $10 \mathrm{~cm}$. The nature of thermal efficiency vs. chimney height has been found concave downward as shown in Figure 3.

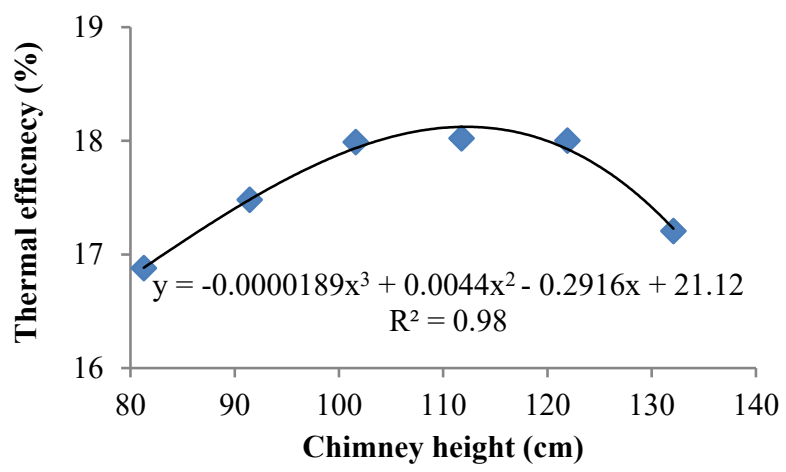

Figure 3: Thermal efficiency of cookstove at different chimney height
The graph for chimney height vs. firepower has been found as bell shape. For shorter chimney height, the draft created due to stack effect is less which results in lower suction of air. For higher chimney height, leading to higher excess air, higher losses of heat through flue gas. The polynomial equation gives optimum efficiency $18.16 \%$ at chimney height $113 \mathrm{~cm}$.

\subsection{Thermal efficiency at different opening area of air fuel inlet}

Size of opening inflences the air flow entering into the combustion chamber and convetion and radiation heat losses. Social factor such as size of fuelwood used also influence the size of the opening [18]. Thermal efficiency of cookstove has been obtained by varying the area of opening from $110 \mathrm{~cm}^{2}$ to $170 \mathrm{~cm}^{2}$ as shown in Figure 4 .

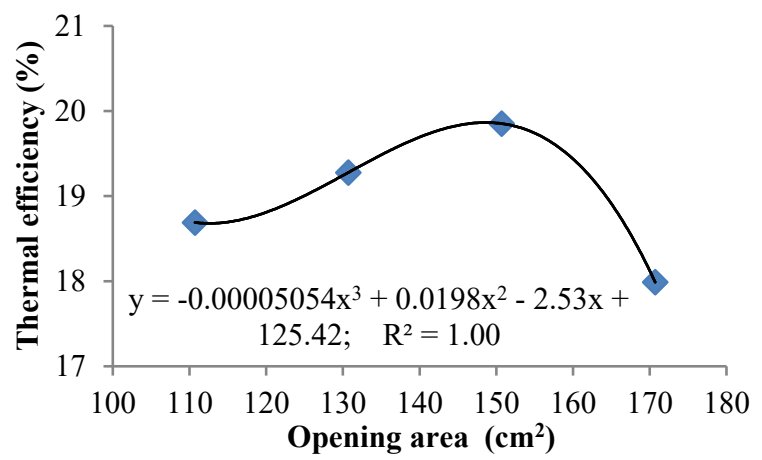

Figure 4: Thermal efficiency of cookstove at different opening

Nature of the graph has been found concave downwards. The maximum efficiency of $19.85 \%$ is obtained at opening area of $148 \mathrm{~cm}^{2}$. The cause of low thermal efficiency at smaller opening is due to more space occupied by fuelwood and less space available for incoming air which results in insufficient air for complete combustion. At larger opening, supply of excess air causes quenching of flame and at the same time more convection and radiation heat losses through openings. From design aspect, minimum opening area of combustion chamber should maintain with the capacity to accommodate at highest firepower [19]. Considering social viability [18] and design aspect, $148 \mathrm{~cm}^{2}$ area is suitable for optimum performance.

\subsection{Thermal efficiency at different size of entry area of inter connecting tunnel}

Thermal efficiency test has been performed by varying entry area for the interconnecting tunnel from $139 \mathrm{~cm}^{2}$ to $14 \mathrm{~cm}^{2}$. Rectangular wall has been raised from bottom of the entry hole to reduce area. 


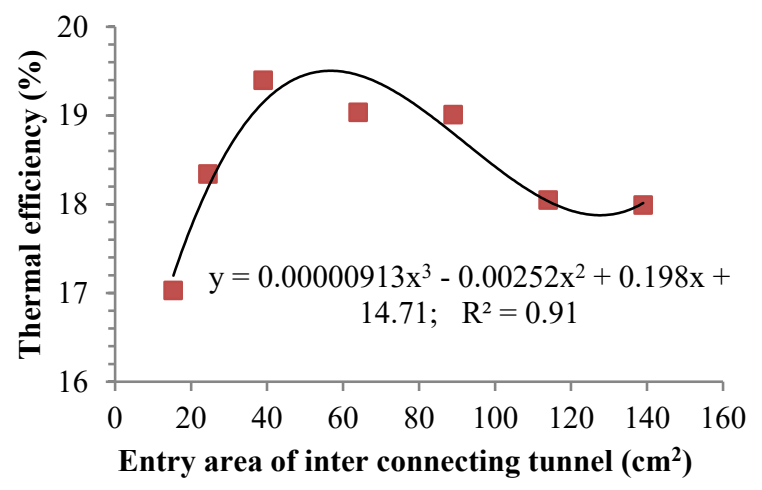

Figure 5: Thermal efficiency of cookstove at different entry area of inter connecting tunnel

As area of interconnecting tunnel decreases, turbulence of air entering the second combustion chamber increases and overall contact time of flue gas increases. Further, reduction of entry area of interconnecting tunnel, results in lack of the area for flow of flue gas. Because of this, insufficient air enters the combustion chamber leading to incomplete combustion and decreased thermal efficiency.

\subsection{Thermal efficiency at different combustion chamber height}

Thermal efficiency test of cookstove has been performed by varying combustion chamber height from $18 \mathrm{~cm}$ to $23 \mathrm{~cm}$ as shown in Figure 6. Result shows that there is linear relationship between thermal efficiency and combustion chamber height. As the combustion chamber height decreases, thermal efficiency increases. This is because the flame directly comes in contact with the pot, transferring more heat to the pot and increasing the thermal efficiency. But the combustion chamber height can be reduced up to a certain limit only. Below the limit, the combustion is incomplete and high soot deposits are formed on the bottom of the pot. Higher combustion chamber height causes quenching of flame and results in decrease of thermal efficiency [11].

By using Herwijn empirical formulae, height of the flame for the stove without grate has been found $19.98 \mathrm{~cm}$ in which thermal efficiency has been found $21.93 \%$ [20]. In this condition, combustion process was found normal and there was no exess soot formation on the pot. For the $18 \mathrm{~cm}$ height combustion chamber, i.e. $2 \mathrm{~cm}$ less than flame height, thermal efficiency has been found $27.83 \%$. This is due to shorter distance between bed of combustion chamber and bottom of the pot, shape factor increases and pot receives more heat at high temperature and thermal efficiency increases. But this leads to increased deposition of soot on the pot, incomplete combustion and increased emission of pollutants. So, combustion chamber height of the cookstove should be equal to flame height.

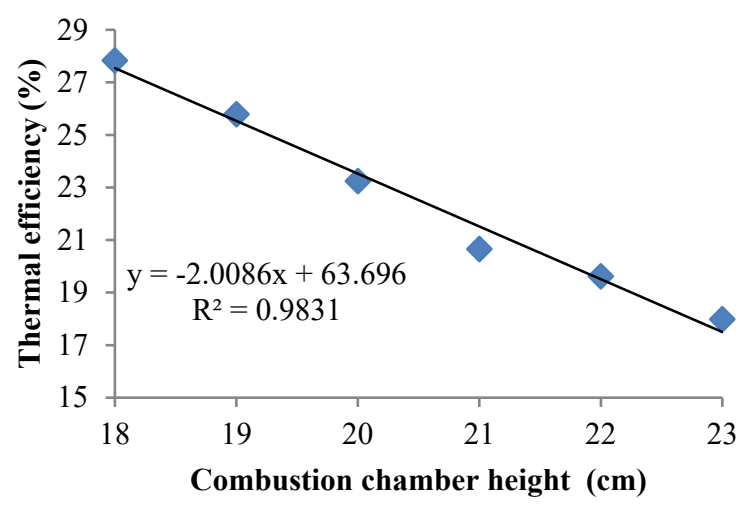

Figure 6: Thermal efficiency of cookstove at different combustion chamber height

\subsection{Thermal efficiency with the use of grate}

Use of grate increases the thermal efficiency of the cookstove [21]. Thermal efficiency of cookstove by using grate of height of $1 \mathrm{~cm}, 2 \mathrm{~cm}$ and $3 \mathrm{~cm}$ have been found $20.61 \%, 21.69 \%$ and $22.70 \%$ respectively as shown Figure 7. This shows that thermal efficiency has been increased by $2.62 \%$ (from 18 to $20.61 \%$ ) by using grate of height $1 \mathrm{~cm}$. Similarly, thermal efficiency increased by $1.08 \%$ and $1.01 \%$ by increasing subsequent each $1 \mathrm{~cm}$ grate height respectively. Use of grate supplies primary air from bed which carries heat from combusted ash and results in improvement of combustion quality. Preheating of incoming air improves quality of combustion and improves thermal efficiency [22].

Grate height has not been increased more than $3 \mathrm{~cm}$ due to size of opening area, size of the fuelwood used and social factor. Here, thermal efficiency has been increased from $17.85 \%$ to $22.69 \%$, i.e. with net increase of $4.84 \%$ with the use of $3 \mathrm{~cm}$ grate but for $3 \mathrm{~cm}$ grate height, the fuelwood has to be cut into small pieces and considering social aspects $3 \mathrm{~cm}$ grate is not a viable option. It has been found that thermal efficiency has been increased by $3.83 \%$ with the use of $2 \mathrm{~cm}$ grate. Socially, technically and geometrically, grate height has been fixed $2 \mathrm{~cm}$.

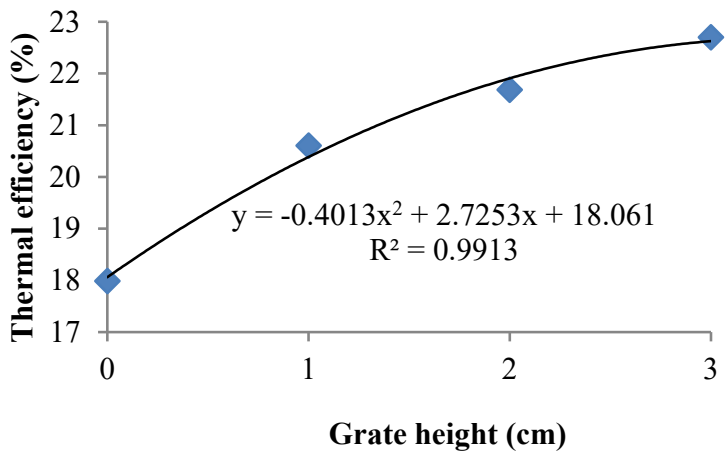

Figure 7: Thermal efficiency of cookstove at different grate height 


\subsection{Thermal efficiency with the use of insulation}

Inner layer of the combustion chamber has been coated by insulating material and effect on efficiency has been observed. Composition of insulating material were Ash $5 / 12$, Saw dust $3 / 12$, Talcum powder $1 / 12$, fire clay $1 / 12$ and Bulk clay $2 / 12$ parts by volume. The main reason for use of this material for insulation is consideration of social aspects. This stove is a nationwide disseminated cookstove and the insulation material should also be locally manufacturable.

Thermal efficiency of cookstove with insulating layer increased from $18 \%$ to $20.21 \%$, i.e. $2.21 \%$ increase in thermal efficiency as shown in Figure 8. This is due to decrease in conductivity which results in less heat transfer to the wall. Also, the temperature of flame increases and ultimately, thermal efficiency increases [23].

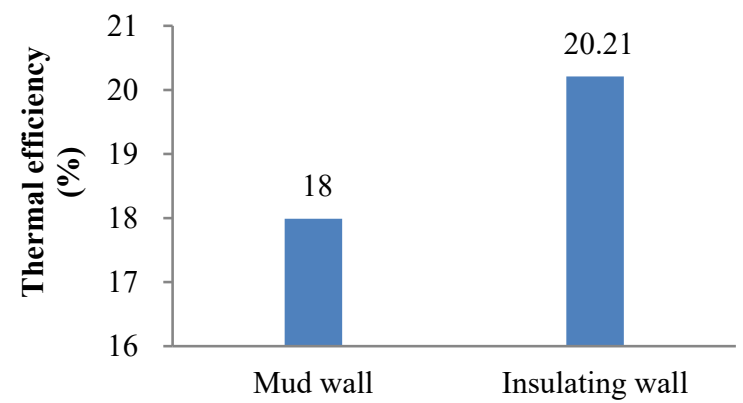

Figure 8: Thermal efficiency of cookstove with use insulating material

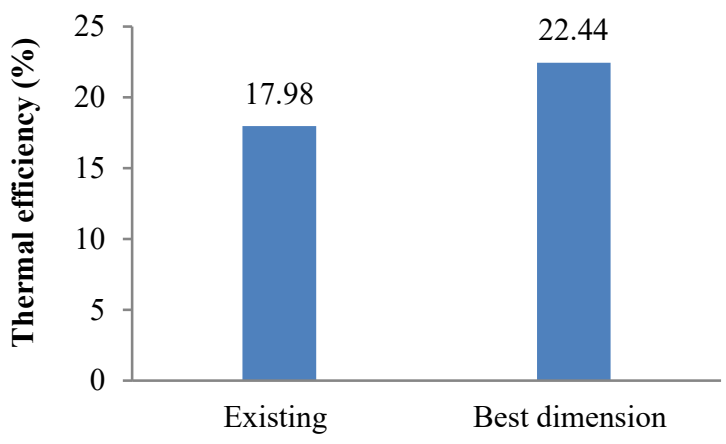

Cookstove dimension

Figure 9: Thermal efficiency comparison at different dimension

\subsection{Thermal efficiency at best condition}

Similarly, best dimension such as chimney height, air fuel inlet opening, entry area of interconnecting tunnel and combustion chamber height have been found $112.88 \mathrm{~cm}$, $148 \mathrm{~cm}^{2}, 56.95 \mathrm{~cm}^{2}$ and $20 \mathrm{~cm}$ respectively. Thermal efficiency of cookstove at overall optimum dimensions have been found at $22.45 \%$. This value is $0.51 \%$ more than individual optimum value at combustion chamber height of $20 \mathrm{~cm}$. So, experimental results show that combustion chamber height is most sensitive parameter for the thermal efficiency. Thermal efficiency of the cookstove at different parametric condition has been shown in Figure 9.

\subsection{Thermal efficiency with the use of grate and insulation}

For the optimum dimension, with the use of $2 \mathrm{~cm}$ grate, thermal efficiency has been increased from $22.45 \%$ to $23.86 \%$; i.e., net increase of $1.41 \%$.

Thermal efficiency of cookstove with the use of insulation on the inner layer of combustion chamber at optimum dimension has been found $23.63 \%$ which is $1.19 \%$ more than in case with use of existing.

Furthermore, using $2 \mathrm{~cm}$ grate on the cookstove fabricated in optimum dimension with insulation in the inner layer of combustion chamber, thermal efficiency has been found $24.70 \%$ which is $1.07 \%$ higher than the case of without use of grate.

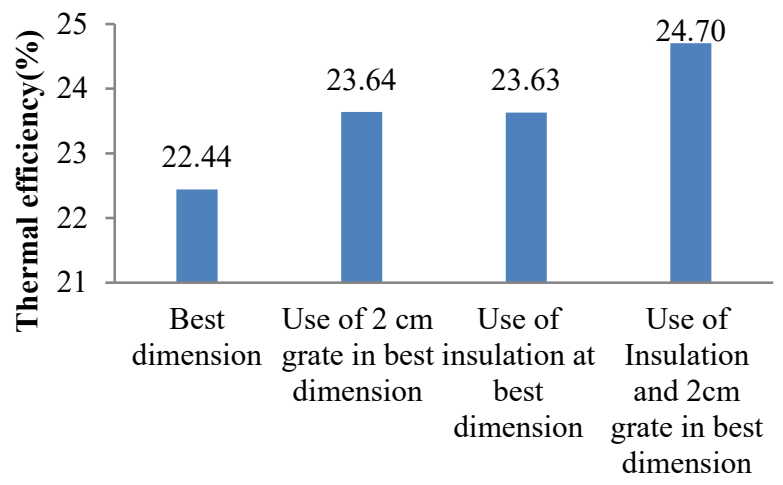

Figure 10: Thermal efficiency with the use of insulation and grate

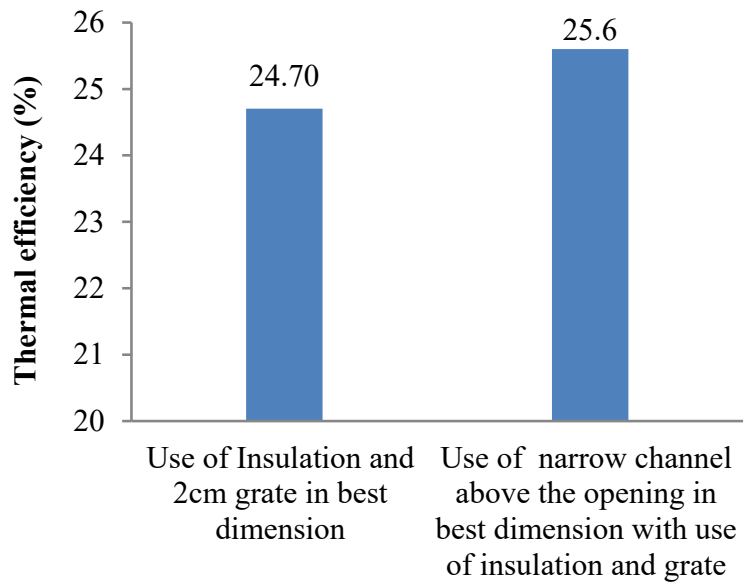

Figure 11: Thermal efficiency of cookstove with formation of narrow channel 


\subsection{Thermal efficiency with formation of narrow channel}

Air has been supplied by making rectangular slot of $4 \mathrm{~cm}$ width and $3.5 \mathrm{~cm}$ above the air fuel inlet. Figure 11 shows thermal efficiency of cookstove has been increased by $0.9 \%$ with formation of narrow channel for the best dimension cookstove with use of insulation and $2 \mathrm{~cm}$ grate.

\section{$4 \quad$ Economic analysis}

Economic analysis has been done for the single cookstove. In economic analysis, Net benefit analysis and marginal abatement cost analysis has been performed. Benefit analysis has been used for decision making for the installation of Improved Cook Stove. Costs includes installation costs (sum of trained technician costs, material cost, the costs of grates and chimneys) as shown in Table 1.

Table 1: Input parameters for economic analysis

\begin{tabular}{|l|l|l|}
\hline \multirow{2}{*}{ Particular } & \multicolumn{2}{|c|}{ Cost of cookstove (NPR) } \\
\cline { 2 - 3 } & Initial & $\begin{array}{l}\text { Yearly } \\
\text { maintenance }\end{array}$ \\
\hline TCS & 1,000 & 100 \\
\hline Existing ICS & 3,490 & 250 \\
\hline Best dimension & 3,490 & 250 \\
\hline $\begin{array}{l}\text { With use of grate at best } \\
\text { dimension }\end{array}$ & 3,790 & 250 \\
\hline $\begin{array}{l}\text { With use of insulation, grate } \\
\text { and formation of narrow } \\
\text { channel in best dimension }\end{array}$ & 4,090 & 450 \\
\hline
\end{tabular}

Marginal abatement cost of cookstove has been performed to identify the cost require for per unit reduction of $\mathrm{tCO}_{2}$ eq. Input parameters for economic analysis shown in Table 2.

Net benefit analysis shows that benefit increases from NPR 16,569 to 23,619 with increase of thermal efficiency from $17.99 \%$ to $25.60 \%$ which is shown in Figure 12 .

Marginal adaptation cost of cookstove has been found lowest NPR 556/ $\mathrm{tCO}_{2}$ eq for $22.4 \%$ thermal efficiency cookstove and highest $735 / \mathrm{tCO}_{2}$ eq for $17.99 \%$ shown in Figure 13. Cost of existing ICS (17.99\% thermal efficiency) and best dimension cookstove (22.40\% thermal efficiency) are same just differences in dimension of cookstove.

From net benefit cost analysis and marginal abatement cost analysis as shown in Figure 12 and Figure 13, cookstove should be made at best dimension $(22.4 \%$ thermal efficiency) cookstove in which thermal efficiency is $4.5 \%$ higher than existing cookstove. While comparing existing and best dimension cookstove, net benefit increases by NPR 5,378 and marginal abatement cost decreases by NPR 179/ $\mathrm{tCO}_{2}$ eq [24] respectively.

Table 2: Input parameters for economic analysis

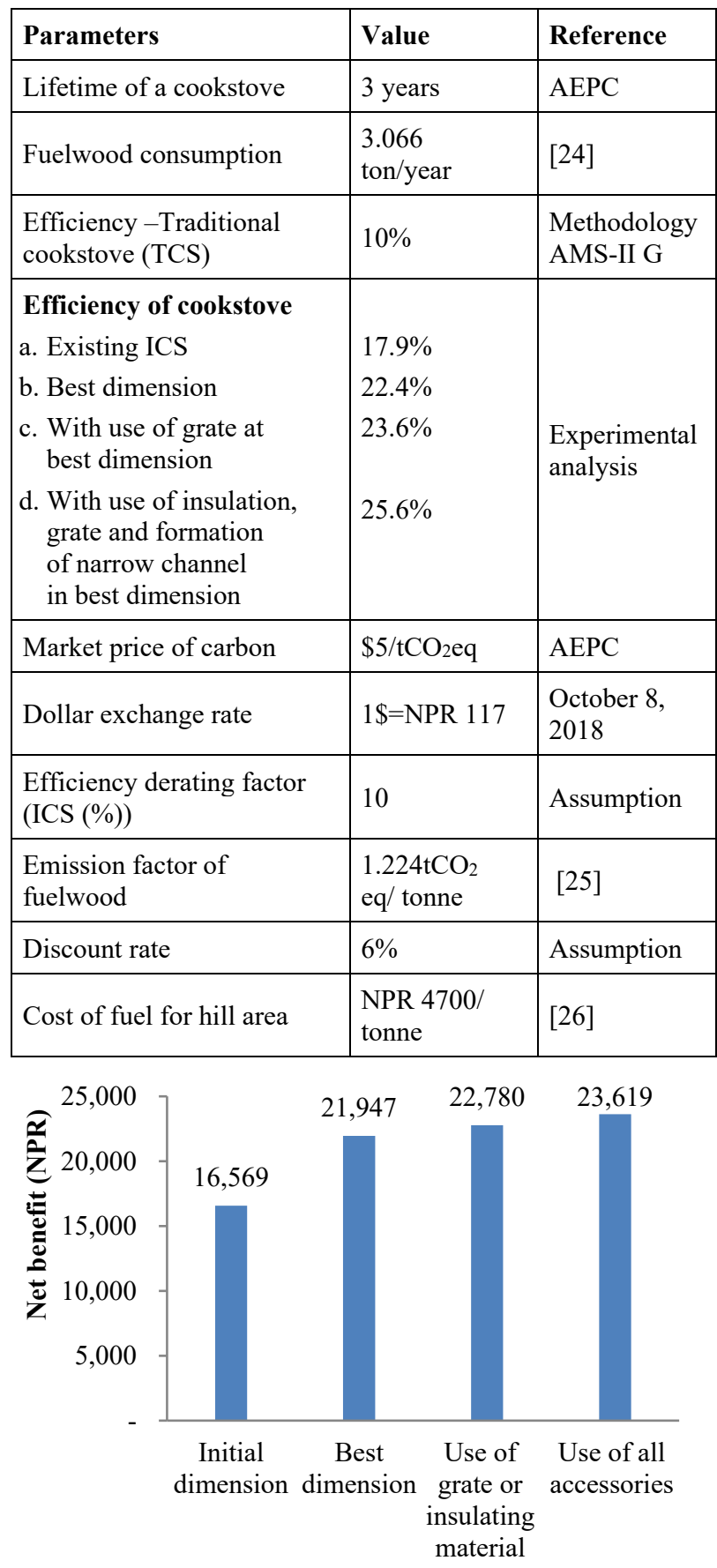

Figure 12: Net benefit of different efficiencies cookstove

\section{Conclusions}




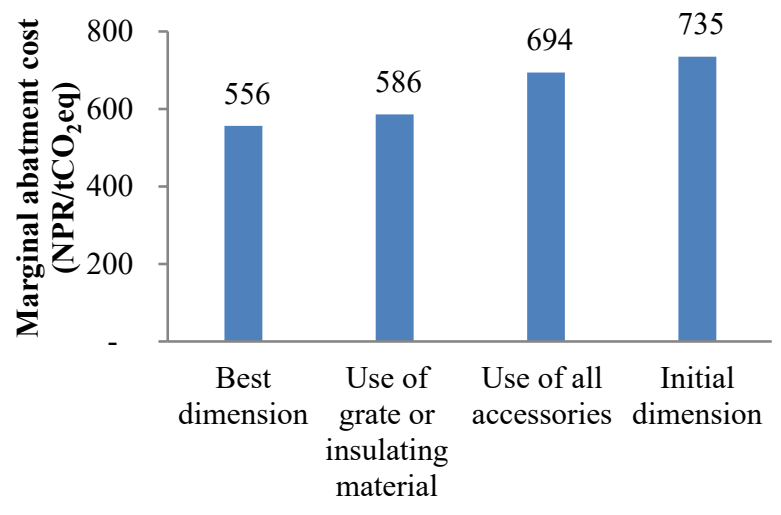

Figure 13: Marginal adaptation cost of different efficiencies cookstove

Following are the conclusion from the study

- Thermal efficiency has been found to be $18 \%$ at optimum firepower of $4.45 \mathrm{~kW}$, i.e., $1.2 \mathrm{~kg} / \mathrm{h}$ feeding rate for the existing cook stove.

- At best dimension of air fuel inlet opening of $148 \mathrm{~cm}^{2}$, combustion chamber height of $20 \mathrm{~cm}$, entry area of interconnecting tunnel $56.95 \mathrm{~cm}^{2}$ and chimney height of $113 \mathrm{~cm}$, thermal efficiency has been found to be $19.45 \%, 21.93 \%, 19.46 \%, 18.16 \%$ respectively.

- Thermal efficiency of cookstove at best possible dimension has been found $22.44 \%$ and $25.6 \%$ for the use of grate, insulating material and narrow channel; i.e., $7.60 \%$ increment from existing design.

- Net benefit has been increased from NPR 16,569 to 23,619 with comparison to traditional cookstove with increased thermal efficiency from $17.99 \%$ to $25.60 \%$.

- Marginal abatement cost of cookstove has been found lowest NPR $556 \mathrm{tCO}_{2} \mathrm{eq}$ for best dimension cookstove and highest for $735 \mathrm{tCO}_{2}$ eq for initial dimension cookstove.

\section{Acknowledgement}

The authors gratefully acknowledge the support from Department of Mechanical Engineering, Pulchowk Campus, Institute of Engineering, Tribhuvan University. Special thanks go to members of Renewable Energy Test Station, Khumaltar, Lalitpur. Finally, we would like to thank the editor and all reviewers for their helpful and incisive comments.

\section{References}

[1] CBS, "Central Bureau of Statistics, Annual household survey 2015/16, 16.," GoN, Kathmandu, Nepal , 2016.
[2] K. Smith, "Health,energy, and green house-gas impacts of biomass combustion in household stoves.Energy Sustainable Development 1994;1(4):239.," 1994.

[3] M. \&. S. H. Sedighi, A comprehensive review of technical aspects of biomass cookstoves. Renewable and Sustainable Energy Reviews, 70(November 2016), 656665., 2017. [Online]. Available: https://doi.org/10.1016/j.rser.2016.11.175.

[4] M. o. P. a. Environment, "Biomass Energy Strategy 2017, (January)," 2017. [Online]. Available: http://www.aepc.gov.np/docs/resource/rescenter/201703 09131259_Biomass Energy Strategy 2073 BS (2017)_English.pdf.

[5] J. B. \&. K. D. H. Kandpal, "Air Pollution From Biomass Combustion in Domestic Cookstove. Renewable Energy, 1481(5), 545-549," 1994. [Online]. Available:

http://www.sciencedirect.com/science/article/pii/096014 $819490216 X ? \mathrm{np}=\mathrm{y}$.

[6] K. K. S. E. \&. V. P. Prasad, "Woodburning Cookstoves. In J. P. Hartnett \& T. F. B. T.-A. in H. T. Irvine (Eds.) (Vol. 17, pp. 159-317)," 1985. [Online]. Available: https://doi.org/https://doi.org/10.1016/S00652717(08)70286-7.

[7] K. B. K. S. R. M. R. \&. R. Sutar, "Biomass cookstoves: A review of technical aspects. Renewable and Sustainable Energy Reviews, 41, 1128-1166.," 2015. [Online]. Available: https://doi.org/10.1016/j.rser.2014.09.003.

[8] S. Sharma, "Biomass fuel systems in Gur \& Khandsari industries in India, Proc. of the National Conference on Wood based energy systems in Rural \& Village industries. FAO \& NSIC, 28-30 Oct. 1991," New Delhi, India., 1991.

[9] J. B. M. E. M. A. J. W. B. \&. D. M. Prapas, "Influence of chimneys on combustion characteristics of buoyantly driven biomass stoves. Energy for Sustainable Development, 23, 286-293," 2014. [Online]. Available: https://doi.org/10.1016/j.esd.2014.08.007.

[10] H. B. P. G. R. \&. A. B. B. Dralami, "Performance Test of Modified Mud Improved Cook Stove. IOE Gratuate Conference.," 2014.

[11] P. K. K. Bussmann P., "Parameter analysis of a simple wood burning cook stove. In: Proceedings of M.

Sedighi, H. Salarian Renewable and Sustainable Energy Reviews 70, 656-665 International Heat Transfer Conference. San Francisco; 1986 p. 3085-3090.," in International Heat Transfer Conference, San Francisco; 2017, p. 3085-30.

[12] S. K. Sharma, " Improved Solid Biomass Burning Cookstoves: a Development Manual (p. 125). Asia Regional Cookstove Programme and Energy Research 
Centre of Panjab University, Chandigarh," 1993.

[Online]. Available: http://www.rwedp.org.

[13] L. S. J. K. Kumar R, "Development, analysis and dissemination of a three pan cook stove. Bangalore: Indian Institute of Science.," 1990. [Online].

[14] P. Gusain, Cooking energy in India. Development Alternatives, New Delhi:: Vikas Publishing House Pvt. Ltd.; India., ., 1990.

[15] S. K. \&. T. S. K. Manoj Kumar, " Design, development and technological advancement in the biomass cookstoves: A review. Renewable and Sustainable Energy Reviews, 26, 265-285. https://doi.org/10.1016/j.rser.2013.05.010," 2013. [Online].

[16] GACC, "The Water Boiling Test Version 4.1.2; Cookstove Emissions and Efficiency in a Controlled Laboratory Setting. Global Alliances for Clearn Cookstoves, 2(January 2013), 52," 2014. [Online]. Available: http://www.cleancookstoves.org/ourwork/standards-and-testing/learn.

[17] J. B. \&. M. R. C. Kandpal, "Combustion of Biomass Fuels in 2 Cookstoves for Their Conservation. Energy Conversion and Management, 36(10), 1015-1021.," 1995. [Online].

[18] U. \&. D. H. B. Sharma, "Performance Assessment and Analysis for Potential Promotion of Improved Cookstoves in Nepal under Market/Non-Market Mechanism," in IOE Graduate Conference (pp. 221231), Lalitpur: Institute of Engineering, Tribhuvan University, 2016.

[19] M. P. \&. K. V. R. Kshirsagar, "User-centric approach for the design and sizing of natural convection biomass cookstoves for lower emissions. Energy, 115, 12021215.," 2016. [Online]. Available: https://doi.org/10.1016/j.energy.2016.09.048.

[20] M. A. Herwijn, "An experimental investigation into the heat transfer from a wood-fire to a pan Herwijn, A . J . $M$. An experimental investigation into the heat transfer from R-632-A by A . J . M . Herwijn Final thesis for the Department," Eindhoven University of Technology , 1984.

[21] M. P. \&. K. V. R. Kshirsagar, " A comprehensive review on biomass cookstoves and a systematic approach for modern cookstove design. Renewable and Sustainable Energy Reviews, 30, 580-603.," 2014. [Online]. Available: https://doi.org/10.1016/j.rser.2013.10.039.

[22] M. S. D. S. P. H. G. O. D. B. R. \&. G. K. Bryden, "Design Principles for Wood Burning Cook Stoves, 38.," 2006.
[23] C. M. De Lepeleire G, " Heat transfer and cooking woodstove modeling. ProcIndian AcadSci (EngSci);6(1):35-46.," 1983.

[24] P. Kandel, P. S. Chapagain, L. N. Sharma and O. R. Vetaas, "Consumption Patterns of Fuelwood in Rural Households of Dolakha District, Nepal: Reflections from Community Forest User Groups (2016)," 2016. [Online]. Available: http://lib.icimod.org/record/31877.

[25] IPCC., "Guideline," 2006. [Online]. Available: https://www.ipcc-ggip.iges.or.jp/public/2006gl/.

[26] N. P. Adhikari, "Spatial variation of biomass energy supply and demand in rural Nepal Retrieved from," 2017. [Online]. Available: www.stiftung-fiatpanis.de/images/DP/DP048.pdf\%0D. 